\title{
Kinerja Usahatani Kopi di Hulu DAS Sekampung, Tanggamus, Lampung
}

\section{Performance of Coffee Agroforestry in Hulu DAS Sekampung, Tanggamus, Lampung}

\author{
Fitriani $^{1}$, Bustanul Arifin ${ }^{2}$, Wan Abbas Zakaria ${ }^{2}$, R. Hanung Ismono ${ }^{2}$ \\ ${ }^{1}$ Politeknik Negeri Lampung \urusan Ekonomi dan Bisnis\Program Studi Agribisnis \\ ${ }^{2}$ Universitas Lampung $\backslash$ Fakultas Pertanian\Program Studi Agribisnis \\ *E-mail : fitriani@polinela.ac.id.
}

\begin{abstract}
Most of the coffee production areas in Lampung are in the vicinity of production forests and protected forests, also a catchment area for watersheds in Lampung, namely Sekampung and Way Seputih watersheds. Continuity of sustainable coffee production lines is an important demand that needs to be done. The application of coffee production systems with shade (agroforestry) in the catchment area is very important in ensuring environmental sustainability. This study aims to analyze the income performance of agroforestry coffee based on the land status in Hulu Das Sekampung. The research uses survey methods. Field data exploration conducted in April-November 2016 is located in Datar Lebuay and Sinar Jawa Villages. Air Naningan, Tanggamus, Lampung. The descriptive statistical analysis method is used to explain the performance of agroforestry coffee production at the research location. Based on the results and discussion it was concluded that farmers with land ownership status had the highest level of coffee farming income compared to the land status of HKm and non-HKm. Agroforestry coffee farmers obtain sources of income from coffee production, MPTS production, and other crop production (multiple cropping). The average contribution of coffee farming income is $22 \%$ of the total farm income. Coffee contributes $22 \%$ to the total income of farmer households. Farmer's household income with the status of land ownership is the highest compared to the land status of HKm and Non-HKm. The diversity of income sources of upstream farmers in the watershed. The villages that come from various vegetation plants are important in maintaining land cover as a catchment area. The practice of agroforestry coffee is an adaptation of sustainable production in the upper watershed Sekampung. The pattern of agroforestry coffee production in the area around protected and watershed forests needs to be continuously developed.
\end{abstract}

Keywords: coffee, agroforestry, sustainable, Sekampung upstream

Disubmit : 8 Juli 2018, Diterima: 8 Agustus 2018, Disetujui : 10 September 2018

\section{PENDAHULUAN}

Kopi merupakan komoditas ekspor strategis nasional. Sebagian besar produksi kopi nasional (77\%) ditujukan untuk memenuhi permintaan ekspor, dan lainnya untuk pasar domestic (BPS-Statistics Indonesia 2015). Seiring upaya peningkatan devisa sektor nonmigas, ekspor kopi diupayakan terus meningkat. Secara umum pangsa kopi Indonesia di pasar dunia pada tahun 2014 mencapai 6,7\%, menurun dari tahun 2013 yang mencapai 8,6\% (ICO 2016). Penurunan ini terjadi selain karena volume perdagangan kopi dunia meningkat, juga karena kontribusi ekspor kopi Indonesia cenderung tumbuh tidak signifikan. Situasi produksi kopi domestik menghadapi ancaman perubahan iklim dan lini produksi yang kurang efisien sebagai penyebab 
utama penurunan produksi kopi. Produksi kopi di tingkat usahatani sebagian besar dilakukan oleh perkebunan kopi rakyat (96\%). Pengelolaan perkebunan kopi yang dilakukan secara modern dengan manajemen korporasi sangat terbatas. Produktivitas perkebunan kopi rakyat rata-rata kurang dari 0,9 ton ha ${ }^{-1}$ (BPS-Statistics Indonesia 2015).

Kinerja produksi kopi nasional secara umum merupakan cerminan persoalan struktural hak kelola lahan, keterbatasan akses input, modal dan pasar pada lini mikro usahatani juga penanganan pasca panen untuk biji kopi berkualitas (Arifin, 2013). Kejelasan hak kelola lahan yang sebagian besar merupakan konsesi hutan produksi juga menjadi persoalan tersendiri. Pilihan produksi kopi dengan tanaman produksi lain dan naungan tegakan tinggi menjadi pilihan wajib bagi petani kopi dengan status hak kelola lahan konsesi. Hal ini juga terjadi pada lahan dengan hak privat, produksi kopi pada lahan dengan topografi dengan elevasi lebih dari $15^{\circ}$ penting menerapkan praktik agroforestri dan konservasi lahan yang memadai. Penanaman kopi dengan tanaman lain dan pohon naungan menjadi pertimbangan penting petani dalam menerapkan prinsip konservasi untuk meminimalkan degradasi lahan. Kombinasi kopi dengan tanaman produksi lain dan naungan merupakan representasi dari penerapan praktik agroforestri di sentra produksi. Upaya meningkatkan produktivitas kopi petani tidak berarti meningkatkan densitas kopi per satuan lahan yang dimiliki, namun lebih ditekankan pada pengayakan sumber penerimaan dari berbagai diversitas tanaman produksi pada setiap lahan petani.Produksi kopi yang menerapkan prinsip produksi berkelanjutan menjadi pilihan penting. Hal ini selaras dengan tuntutan pembangunan pertanian berkelanjutan yang menjadi target pembangunan setiap Negara di dunia ( global sustainable development goals).

Bagaimana praktik produksi kopi di tingkat petani saat ini menjadi fokus penting dalam jejaring bisnis pasar kopi global.Tuntutan produksi kopi berkelanjutan dari konsumen pasar global terus menguat. Saat ini pangsa ekspor kopi Indonesia dengan label sustainable mencapai $10 \%$ dari total volume ekspor kopi nasional dengan trend terus meningkat. Perbaikan lini produksi kopi berkelanjutan menjadi bagian integral dalam perbaikan sistem agribisnis kopi nasional. Perkebunan kopi di Lampung adalah perkebunan rakyat. Sebagian besar berada di Kabupaten Lampung Barat seluas 60.273 ha $(43,18 \%)$ dan Tanggamus seluas 44.330 ha (31.76\%). Produksi kopi Lampung Barat mencapai 59.107 ton (42,35\%), sedangkan Tanggamus sebesar 36.520 ton (26,16\%) (Badan Pusat Statistik Lampung 2015).

Produksi kopi berkelanjutan berarti praktik budidaya kopi yang menerapkan best practice agroforestry yang menguntungkan secara ekonomi dan memberikan akses kesejahteraan sosial bagi petani. Areal produksi kopi di Lampung sebagian besar berada di sekitar kawasan hutan produksi dan hutan lindung,juga merupakan daerah tangkapan air bagi DAS yang ada di Lampung, yaitu DAS Sekampung dan Way Seputih.Pengembangan produksi kopi pada wilayah hulu DAS Sekampung dapat terus dilakukan dengan menerapkan prinsip-prinsip konservasi (Banuwa et al. 2008). DAS merupakan suatu area yang terhubung secara hidrologi dan dalam pengelolaan secara optimal membutuhkan koordinasi semua penggunadalam penggunaan sumber daya alamnya (Ekawati 2015). DAS dalam spektrum luas memberikan jasa ekologi, ekonomi dan sosial bagi masyarakat luas.

Usahatani kopi dalam sistem agroforestri mampu menyediakan jasa ekosistem yang dapat memenuhi tuntutan ekonomi dan sosial masyarakat. Beberapa penelitian menujukkan bahwa agroforestri pada usahatani kopi rakyat selain dapat dapat mengefisienkan biaya usahatani (Haggar et.al. (2015); Noponen, et.al., 2013; Binam, et.al., 2015; Buechley et al., 2015, and Evizal, et.al., 2012) juga memberikan manfaat jasa lingkungan. Kopi dengan agroforestri disebut juga kopi multistrata merupakan jenis kebun lindung yang dapat memberikan jasa lingkungandan sekaligus meningkatkan kesejahteraan petani. Jasa lingkungan merupakan bentuk eksternalitas positif yang dinikmati secara luas oleh masyarakat. Kopi agroforestri menjadi salah satu upaya manajemen adaptif berkelanjutan untuk menangani risiko kerusakan ekosistem hutan (Bernard et al. 2014; Buongiorno and Zhou 2015; Eakin, et al. 2014; FAO 2014; Foran et al. 2014; Fu 
et al. 2009). Sebagaimana perkebunan teh juga menyediakan ekstenalitas positif jasa ekologidi China (Xue et al. 2013).

Oleh karena itu, pola produksi kopi agroforestri di kawasan sekitar hutan lindung dan DAS perlu terus dikembangkan. Pola usahatani, perubahan penggunaan lahan, intensifikasi tutupan/vegetasi tanaman menjadi faktor yang mempengaruhi kondisi dan kualitas pasokan DAS Sekampung (Somura et al. 2018). Keputusan akhir penting melibatkan interaksi antara pandangan aspek keragaman sosial, ekonomi, dan ekologi dari pelaku.Pengelolaan DAS dan praktik kopi agroforestri menjadi langkah penting dalam memastikan praktik berkelanjutan.Bagaimana performa kopi agroforestri yang dilakukan petani di hulu DAS Sekampung dapat menjawab tuntutan keberlanjutan menjadi penting dilakukan. Penelitian ini bertujuan untuk menganalisis pendapatan kinerja kopi agroforestri berdasarkan status lahan di Hulu Das Sekampung.

\section{METODE PENELITIAN}

Penelitian menggunakan metode survei. Eksplorasi data lapangan dilakukan pada bulan AprilNovember 2016 berlokasi di Desa Datar Lebuay dan Sinar Jawa Kec. Air Naningan, Tanggamus, Lampung. Penentuan lokasi dilakukan secara purposive dengan pertimbangan utama bahwa kedua desa tersebut berada di daerah hulu DAS Sekampung dan berada diantara dua sungai besar yang merupakan sumber utama Waduk Batu Tegi. Dua sungai besar tersebut adalah Way Sekampung dan Way Sangarus. Pengambilan sample responden ditentukan dengan metode stratified random sampling berdasarkan status hak kelola lahan. Hak kelola lahan di lokasi penelitian meliputi: hak prifat/milik, hak HKm (Hutan Kemasyarakatan/ kemitraan/konsesi hutan lindung), dan yang terakhir yang berada pada kondisi tidak termasuk ke dalam golongan keduanya (non HKm). Jumlah total responden sebanyak 400 petani. Metode analisis statistik deskriptif digunakan untuk menjelaskan kinerja produksi dan pendapatan kopi agroforestri di lokasi penelitian. Pengujian statistika Independent samples t-test digunakan untuk membandingkan pendapatan kopi pada kelompok hak kelola lahan yang berbeda. Hipotesis yang diajukan dalam uji ini adalah:

$$
\text { Ho: } \mu 1=\mu 2
$$

(Tidak ada perbedaan yang signifikan antara pendapatan petani kopi hak milik (private) dan petani HKm)

$$
\text { Ha: } \mu 1 \neq \mu 2
$$

(Ada perbedaan yang signifikan antara pendapatan petani kopi hak milik (private) dan petani HKm)

\section{HASIL DAN PEMBAHASAN}

Demografi Responden

Berdasarkan hasil survei diketahui bahwa responden adalah 334 orang laki-laki dan 66 perempuan. Keberadaan perempuan menunjukkan bahwa pengelolaan usahatani kopi memberikan ruang yang sama antara laki-laki dan perempuan. Selain status marital (orang tua tunggal), kondisi ekonomi menjadi faktor utama perempuan mengambil peran sebagai kepala keluarga.Budaya masyarakat juga secara terbuka memberikan ruang seluasnya bagi perempuan untuk melakukan usahatani maupun usaha produktif lainnya sesuai dengan kemampuannya.

Berdasarkan umur, karakteristik responden di daerah penelitian paling tua berusia 81 tahun dan yang paling muda 21 tahun. Pendidikan paling tinggi adalah lulusan pendidikan tinggi, dan yang paling rendah tidak sekolah. Pendidikan sekolah dasar (62\%), SMP (24\%) dan SMA (10\%). Terdapat tiga orang responden dengan tingkat pendidikan tinggi. Keberadaan responden yang telah memperoleh pendidikan tinggi sangat menggembirakan. Keberadaan responden dengan latar belakang pendidikan tinggi menjadi salah satu indikator, bahwa masyarakat di daerah penelitian berpikiran maju. Pengalaman usahatani kopi paling lama mencapai 56 tahun, sedangkan pemula baru berpengalaman satu tahun, sebagian besar telah 
memiliki pengalaman di atas 10 tahun (50\%). Secara umum, responden telah mendapatkan pendidikan dasar dan menengah. Pendidikan dan pengalaman ini menjadi modal dasar petani untuk dapat mengembangkan tingkat ketempilan dan adopsi teknologi baru yang penting dalam peningkatan kapasitas usahataninya.

Rumah tangga responden sebagian besar memiliki tanggungan anak dan dewasa. Rumah tangga paling banyak memiliki 7 orang dewasa dalam tanggungan dan paling sedikit 1 orang. Sementara tanggungan anak paling banyak 10 orang dan yang paling sedikit belum punya tanggungan. Kondisi ini menggambarkan ketersediaan tenaga kerja dalam keluarga yang dimiliki oleh rumah tangga responden. Keberadaan tenaga kerja keluarga sangat membantu terselenggaranya usahatani skala rakyat. Intensitas pengelolaan usahatani petani sangat tergantung pada ketersediaan tenaga kerja dalam keluarga pada situasi tenaga kerja luar keluarga cukup tinggi tingkat upahnya. Sementara gambaran tanggungan anak menunjukkan bahwa rumah tangga petani memiliki tanggungan yang membutuhkan alokasi sumberdaya keluarga yang tinggi, sehingga dapat menimbulkan trade off dengan kebutuhan sumberdaya untuk usahataninya.

\section{Status hak kelola lahan}

Aspek yuridis formal penguasaan lahan di daerah penelitian dikelompokkan menjadi tiga, yaitu pribadi/marga, HKm, dan non HKm. Petani dengan status lahan pribadi atau marga memiliki dokumen legal dari Negara atau Pemerintah Daerah terkait hak properti yang dimilikinya. Petani dengan status HKm adalah petani yang mendapatkan izin regulasi pengelolaan lahan di kawasan hutan lindung dari pemerintah melalui Kementrian Kehutanan dalam hal ini KPHL Batu Tegi. Petani non HKm, berarti status lahan kelolanya tidak masuk dalam kategori pribadi/marga maupun $\mathrm{HKm}$. Berdasarkan rekapitulasi status pengelolaan lahan, rincian responden dapat dilihat pada Tabel 1.

Tabel 1. Status penguasaan lahan responden

\begin{tabular}{lccc}
\hline \multicolumn{1}{c}{ Nama Dusun } & Pribadi/Marga & HKm & Non HKm \\
\hline Cita Laksana & 12 & 30 & 22 \\
Sekampung Kuning & 2 & 23 & 13 \\
Talang Tengah & 12 & 25 & 18 \\
Ciherang & 1 & 30 & 0 \\
Talang Damar & 2 & 13 & 4 \\
Cita Laksana & 12 & 30 & 22 \\
\hline Datar Lebuay total & 29 & 121 & 57 \\
\hline Sinar Jawa & 11 & 15 & 13 \\
Sukoharjo & 17 & 21 & 24 \\
Bungur I & 2 & 9 & 9 \\
Bungur II & 9 & 18 & 10 \\
Talang Sebaris & 3 & 20 & 12 \\
\hline Sinar Jawa total & 42 & 83 & 68 \\
\hline \multicolumn{1}{c}{ Total } & 71 & 204 & 125 \\
\hline
\end{tabular}

Berdasarkan Tabel 1 bahwa sebagian besar responden adalah petani anggota kelompok HKm. Sebagian besar izin HKm diperoleh pada pasca reformasi tahun 2000-an. Petani HKm paling banyak tinggal di Desa Datar Lebuay. Lahan garapan yang mendapat hak kelola berada di Register 39 di bawah otorita pengelolaan KPHL Batu Tegi. Sementara untuk hak kelola privat/milik/marga banyak berada di Desa Sinar Jawa. Mereka ini sebagian besar memiliki tanah marga pemberian Negara di awal kedatangan mereka. Petani dengan kepelikan marga di Datar Lebuay saat ini merupakan generasi kedua. Pada tahun 2015 sejumlah baru 250 bidang lahan marga di Pekon Datar Lebuay mendapatkan sertifikat tanah hak milik dari Kantor BPN sedangkan yang lain sedang dalam proses pengajuan. Secara kronologi sejarah, keberadaan petani yang masuk dalam kelompok HKm sebagian besar merupakan migrasi penduduk yang pada awalnya 
terusir dari Reg. 39 dan pemukim pendatang baru yang tidak terkait dengan penduduk awal. Setelah masa reformasi terjadi eksodus penduduk lokal dan sekitarnya kembali ke kawasan di Reg. 39. Hal ini secara dapat dilihat dari perubahan landscape penggunaan lahan di hulu DAS Sekampung yang ada di Reg. 39. Selama periode 2005-2010 terjadi perubahan land use dari hutan lindung berubah peruntukan menjadi pertanian lahan kering sampai $740 \%$.

Eksodus warga pasca reformasi tersebut menyebabkan petani dengan status non-HKm masih cukup tinggi di kawasan Reg 39. Responden dengan lahan non HKm sebagian besar berada di Dusun Sukoharjo Sinar Jawa, dan Dusun Cita Laksana Datar Lebuay. KPHL Batu Tegi terus berupaya untuk menertibkan petani dengan status non-HKm, diantaranya dengan membuka kesempatan untuk mengikuti program kemitraan. Hal ini sesuai dengan peraturan kementrian kehutan yang membuka kesempatan seluasnya bagi kelompok masyarakat/pelaku usaha untuk berpartisipasi dalam pengelolaan sumberdaya hutan secara berkelanjutan.

\section{Produksi kopi}

Berdasarkan rekap penggunaan input produksi yang digunakan pada usahatani kopi dapat dilihat bahwa umumnya petani kopi menggunakan pupuk urea, SP36, KCl, dan NPK, juga pupuk kandang (Tabel 2). Populasi tanaman kopi per luas areal tanam yang berbeda menjadi pembeda besaran alokasi pupuk per tanaman. Populasi tanaman kopi yang dimiliki oleh petani hak milik/marga sebesar 1.653 pohon.ha ${ }^{-1}$. Pada anggota $\mathrm{HKm}$, merupakan rataan populasi pohon kopi yang paling tinggi mencapai sebesar 1.957 pohon.ha ${ }^{-1}$. Sementara untuk non-HKm, mereka memiliki populasi tanaman kopi sebesar 498 pohon.ha $^{-1}$. Kondisi ini menjadi indikasi bahwa biodiversitas pada lahan $\mathrm{HKm}$ menunjukan keragaman yang lebih tinggi dibandingkan pada lahan hak milik maupun non-HKm. Kondisi ini juga terjadi di Kecamatan Pulau Panggung,Tanggamus (Fitriani, et al. 2018). Gambar 1 menampilkan situasi produksi kopi pada status lahan yang berbeda.

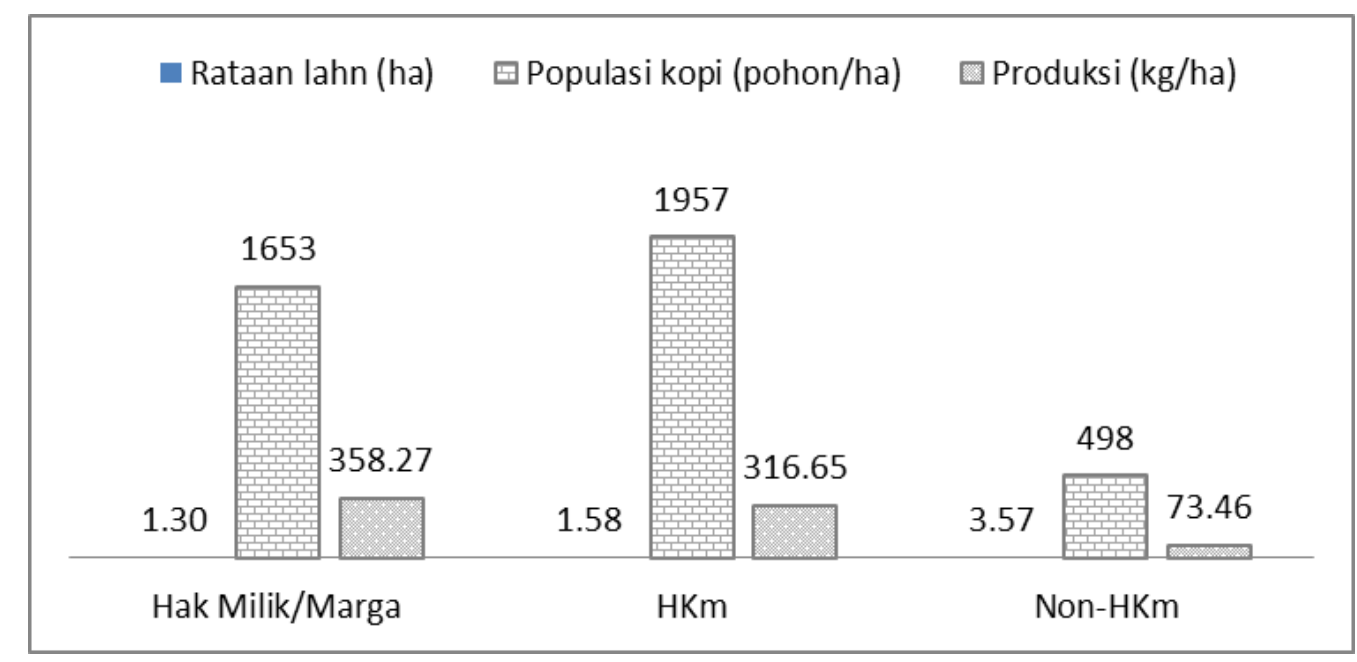

Gambar 1. Situasi produksi kopi pada status lahan

Selanjutnya berdasarkan alokasi penggunaan input produksi, Tabel 2 menyajikan rataan penggunaan dan harga pupuk pada usahatani kopi petani responden. 
Tabel 2. Rataan aplikasi dan harga pupuk petani responden

\begin{tabular}{ccc}
\hline Rata-rata aplikasi pupuk & $\mathrm{Kg}^{-\mathrm{ha}^{-1}}$ & $\mathrm{Rp} \cdot \mathrm{kg}^{-1}$ \\
\hline Urea & 108 & 3,643 \\
SP36 & 113 & 2,426 \\
KCl & 14 & 3,900 \\
NPK & 19 & 12,600 \\
Pupuk lain (kandang) & 91 & 1,485 \\
\hline
\end{tabular}

Selain biaya pupuk petani juga mengeluarkan biaya tenaga kerja dan pengendalian organisme penganggu tanaman (OPT) kopi. Biaya total usahatani kopi paling tinggi mencapai Rp 2,7 juta dikeluarkan oleh petani dengan status lahan hak milik. Petani HKm mengeluarkan biaya produksi kopi sebesar Rp 2,2 juta, sedangkan alokasi biaya produksi paling rendah dikeluarkan oleh petani non-HKm sebesar Rp 392 ribu (Tabel 3). Penggunaan tenaga keluarga cukup tinggi mencapai 37 HOK per musim, sedangkan penggunaan tenaga kerja luar keluarga sebanyak $30 \mathrm{HOK}$ per musim. Intensitas penggunaan tenaga kerja paling tinggi untuk kegiatan panen dan pasca panen. Upah rataan tenaga kerja di lokasi penelitian sebesar Rp $54.000 / \mathrm{HOK}$.

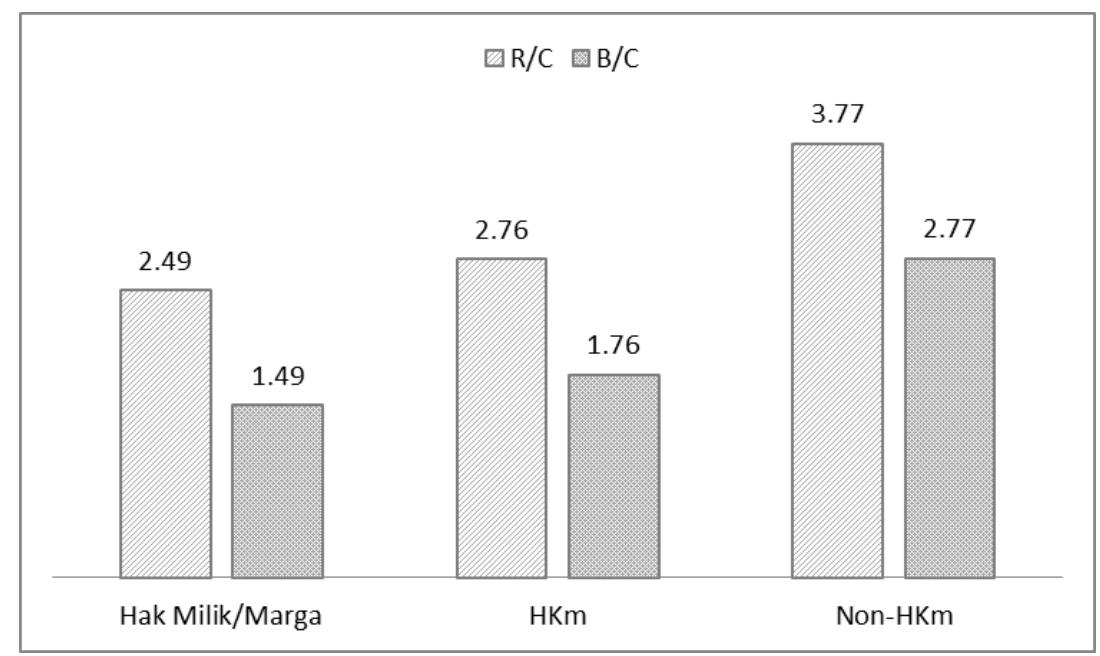

Gambar 2. Nilai R/C dan B/C usahatani kopi berdasarkan status hak kelola lahan

Pada Tabel 3 ditampilkan tingkat penerimaan dan produksi kopi yang dihasilkan petani pada berbagai tingkat hak kelola lahan yang berbeda. Produksi kopi paling tinggi dihasilkan oleh petani hak milik mencapai 358,3 kg.ha- ${ }^{-1}$, petani HKm mampu mendapatkan produksi $317 \mathrm{~kg} \cdot \mathrm{ha}^{-1}$, sedangkan paling rendah adalah petani non-HKm dengan produksi $74 \mathrm{~kg} \mathrm{ha}^{-1}$. Petani $\mathrm{HKm}$ berkewajiban untuk menanam tanaman tegakan dengan intensitas yang tinggi (200-400 pohon) diantara populasi tanaman kopi sebagai tanggung jawab atas hak kelola lahan di kawasan hutan lindung. Tingkat penerimaan usahatani kopi petani dengan hak milik mencapai $\quad$ Rp 4,1 juta.ha ${ }^{-1}$, HKm sebesar Rp 3,9 juta.ha ${ }^{-1}$, sedangkan HKm sebesar Rp 1,08 juta.ha $^{-1}$. Nilai $\mathrm{R} / \mathrm{C}$ dan $\mathrm{B} / \mathrm{C}$ rasio usahatani kopi memenuhi syarat sebagai usaha yang menghasilkan manfaat lebih besar dari korbanan yang dikeluarkan. Gambaran nilai R/C dan B/C usahatani kopi dapat dilihat pada Gambar 2. 
Fitriani., dkk: Kinerja Usahatani Kopi di Hulu DAS Sekampung, Tanggamus, Lampung

Tabel 3. Rata-rata produksi dan biaya usaha tani kopi per hektar per tahun

\begin{tabular}{lrrr}
\hline Uraian & \multicolumn{3}{c}{ Status Pengelolaan Lahan } \\
\hline & HKm & Non-HKm \\
Produksi (kg/ha) & 358 & 317 & 73.46 \\
Harga Jual rataan (Rp/kg) & 19,352 & 19,705 & 20126.40 \\
Penerimaan kopi (Rp/ha) & $6,933,235$ & $6,239,479$ & $1,478,387.87$ \\
Biaya Utama & & & \\
Sewa lahan (Rp/th) & $1,000,000$ & $1,000,000$ & \\
Biaya Pupuk & 488,401 & 159,670 & 40,135 \\
Biaya Pengendali OPT & 454,577 & 390,686 & 172,146 \\
Biaya TK & 837,746 & 707,649 & 179,888 \\
Total Biaya (Rp/ha) & $2,780,725$ & $2,258,006$ & 392,169 \\
Pendapatan kopi (Rp/ha) & $4,152,510$ & $3,981,473$ & $1,086,219$ \\
R/C & 2.49 & 2.76 & 3.77 \\
B/C & 1.49 & 1.76 & 2.77 \\
\hline
\end{tabular}

Pada Gambar 2 dapat dilihat bahwa berdasarkan nilai R/C dan B/C usahatani kopi dalam jangka pendek memiliki nilai yang lebih besar dari satu dan nol. Hal ini menunjukkan bahwa pada kondisi status lahan yang berbeda, usahatani kopi dalam jangka pendek memiliki tingkat pengembalian usaha yang menguntungkan. Selanjutnya, sebagaimana informasi di awal, petani tidak hanya mengelola usahatani kopi, juga usahatani tanaman lainnya (multiple cropping) seperti lada, pisang, dll., juga tanaman tegakan (buah dan kayu) sebagai naungan untuk mengoptimalkan pemanfaatan lahan dan meningkatkan pendapatan petani. Pembahasan kinerja produksi kopi tidak dapat dilepaskan dari perform agroforestri yang merepresentasikan penanaman aneka tanaman pada lahan usahatani kopi. Tabel 4 menunjukkan tingkat penerimaan usahatani selain kopi yang diterima oleh petani. Penerimaan itu berasal dari penanaman pohon naungan multi fungsi (MPTS=multipurpose tree species; buah-buahan dan kayu) dan tanaman multiple cropping seperti lada, kakao, dan pisang.

Tabel 4. Rata-rata penerimaan dan biaya usahatani non kopi berdasarkan status lahan

\begin{tabular}{lrrr}
\hline Komponen & Hak Milik/Marga & \multicolumn{1}{c}{ HKm } & Non-HKm \\
\hline Penerimaan TS 1 (Rp/ha) & $34,529,572$ & $13,470,305$ & $7,925,141$ \\
Penerimaan TS 2(Rp/ha) & $1,688,703$ & $1,612,429$ & 458,361 \\
Biaya TS & $5,783,650$ & $5,783,650$ & 664,533 \\
Pendapatan TS & $30,434,625$ & $9,299,084$ & $7,718,970$ \\
Penerimaan MPTS 1 (buah dan rempah) & $34,529,572$ & $13,470,305$ & 618,038 \\
Penerimaan MPTS 2 & $1,688,703$ & $1,612,429$ & 201,560 \\
Biaya MPTS & $2,039,566$ & 981,812 & 664,533 \\
Pendapatan MPTS & $34,178,709$ & $14,100,922$ & 155,066 \\
\hline
\end{tabular}

Pada Tabel 4 dapat dilihat bahwa sumbangan penerimaan tanaman lada sangat tinggi dan mendominasi total penerimaan usahatani selain kopi. Situasi ini tidak terlepas dari tingkat harga lada yang sangat baik diterima petani selama kurun waktu tiga tahun terakhir (2015-2018) yang mencapai lebih dari Rp $100 \mathrm{ribu} / \mathrm{kg}$. Penerimaan dari MPTS merupakan bagian penting dalam struktur pendapatan keluarga petani, terutama dalam upaya menyediakan sumber pendapatan bulanan, mengingat hasil panen yang memiliki waktu yang berbeda-beda. Struktur pendapatan rumahtangga petani kopi dapat dilihat pada Tabel 5. 
Tabel 5. Struktur pendapatan rumahtangga responden

\begin{tabular}{lr}
\hline \multicolumn{1}{c}{ Uraian } & Rataan \\
\hline Pendapatan kopi (Rp) & $6,933,235$ \\
Pendapatan usaha tani non kopi (Rp) & $21,454,527$ \\
Pendapatan total usaha tani (Rp) & $27,270,856$ \\
Pendapatan di luar usaha tani (Rp) & $3,246,831$ \\
Pendapatan Total RT (Rp) & $30,099,425$ \\
(\%) kopi terhadap Pendapatan Usahatani & $24 \%$ \\
(\%) kopi terhadap Pendapatan Total & $22 \%$ \\
\hline
\end{tabular}

Berdasarkan informasi struktur pendapatan rumah tangga petani kopi disadari bagaimana pengelolaan lahan dilakukan oleh petani dalam mengoptimalkan sumber pendapatan keluarga dilakukan. Nilai ini menunjukkan bahwa petani kopi dalam mengoptimalkan lahan yang dimiliki bukan hanya berorientasi pada hasil kopi, namun produksi dari beragam vegetasi yang menjadi representasi budaya agroforestri telah mulai mengkristal dan menjadi keniscayaan untuk mewujudkan produksi berkelanjutan di hulu DAS Sekampung dan Reg. 39 Batu Tegi.

Kontribusi pendapatan dari usahatani kopi mencapai sebesar $24 \%$ dari pendapatan usahatani. Sementara kontribusi kopi terhadap total pendapatan rumahtangga berkontribusi sebesar $22 \%$. Gambaran struktur pendapatan rumah tangga petani kopi mencerminkan keragaman sumber pendapatan perdesaan yang berkembang dalam suatu daerah. Hal ini berarti responden di lokasi penelitian bergantung secara dominan terhadap usahatani dan aktivitas produksi pertanian menjadi sandaran sumber pendapatan keluarga. Sumber pendapatan rumah tangga yang secara dominan masih berbasis lahan di wilayah hulu DAS Sekampung perlu memberikan perhatian lebih pada aspek konservasi lahan dan tutupan vegetasi yang menjaga daerah tangkapan air. Oleh karena itu, untuk dapat menjamin bahwa aktivitas produksi pertanian di wilayah hulu DAS Sekampung berkelanjutan, informasi sumber pendapatan keluarga menjadi basis. Adalah menjadi keniscayaan bahwa program kebijakan restorasi daerah tangkapan air dan hutan lindung wajib berjalan selaras dengan upaya pengayaan sumber-sumber pendapatan baru bagi asyarakat perdesaan, sehingga dapat meminimalkan trade off antara manfaat ekonomi dan manfaat lingkungan.

Berdasarkan hasil analisis uji beda (lampiran) menunjukkan bahwa $\mathbf{H}_{\mathbf{1}}$ diterima, sehingga dapat disimpulkan bahwa ada perbedaan yang signifikan antara pendapatan petani kopi hak milik (private) dan petani HKm. Nilai |t-hitung| sebesar 3,06 dengan nilai signifikansi $p$-value sebesar 0,023. Begitu pula pada uji beda antara petani hak milik dengan non-HKm menunjukkan bahwa nilai |t-hitung| sebesar 5,414 dengan nilai signifikansi $p$-value sebesar 0,001. Hal ini menunjukkan bahwa t-hitung lebih besar dari t-tabel (5,414> $2,779)$ dan nilai signifikansi $p$-value lebih besar dari taraf signifikansi $5 \%(0,001<0,05)$, yang artinya bahwa $\mathbf{H}_{\mathbf{1}}$ diterima, maka dapat disimpulkan bahwa ada perbedaan yang signifikan antara pendapatan petani kopi hak milik (private) dan petani non-HKm.Nilai rata-rata pendapatan petani kopi hak milik lebih tinggi dari petani HKm dan non-HKm menunjukkan bahwa rataan pendapatan petani kopi hak milik lebih tinggi dari petani $\mathrm{HKm}$ dan non-HKm.

\section{KESIMPULAN}

Petani kopi dengan agroforestri memperoleh sumber pendapatan dari produksi kopi, produksi MPTS, dan produksi tanaman lain (multiplecropping). Rerata sumbangan pendapatan usahatani kopi sebesar $24 \%$ dari total penerimaan usahatani. Kopi berkontribusi sebesar $22 \%$ terhadap total pendapatan rumahatangga petani. Pendapatan rumahtangga petani dengan status lahan hak milik paling tinggi dibandingkan dengan status lahan HKm dan Non-HKm. Keragaman sumber pendapatan petani di hulu DAS Sekampung yang berasal dari berbagai vegetasi tanaman penting dalam menjaga tutupan lahan sebagai wilayah tangkapan air.Praktik kopi agroforestri menjadi adaptasi produksi berkelanjutan di hulu DAS Sekampung. 
Fitriani., dkk: Kinerja Usahatani Kopi di Hulu DAS Sekampung, Tanggamus, Lampung

\section{UCAPAN TERIMA KASIH}

Kementrian Riset, Teknologi, dan Pendidikan Tinggi melalui Hibah Doktor

\section{DAFTAR PUSTAKA}

Arifin, B., 2013. On the Competitiveness and Sustainability of the Indonesian Agricultural Export Commodities. , 1(June), pp.81-100.

Badan Pusat Statistik Lampung, 2015. Lampung Dalam Angka, 2015, Bandar Lampung: Lampung Statistical Board.

Banuwa, I.S. et al., 2008. Land capability evaluation of Upper Sekampung watersheds. Jurnal Tanah Tropika, 13(2), p.145-153 (in Indonesian with English summary).

Bernard, F. et al., 2014. Social actors and unsustainability of agriculture. Current Opinion in Environmental Sustainability, 6(1), pp.155-161.

Binam, J.N., Place, F. \& Kalinganire, A., 2015. Effects of farmer managed natural regeneration on livelihoods in semi-arid West Africa.

BPS-Statistics Indonesia, 2015. Statistik Indonesia, Jakarta: BPS Indonesia.

Buechley, E.R. et al., 2015. Importance of Ethiopian shade coffee farms for forest bird conservation. Biological Conservation, pp.1-11.

Buongiorno, J. \& Zhou, M., 2015. Adaptive economic and ecological forest management under risk.

Eakin, H. et al., 2014. Adaptation in a multi-stressor environment: perceptions and responses to climatic and economic risks by coffee growers in Mesoamerica. Environ Dev Sustain, 16, pp.123-139.

Ekawati, S., 2015. Integrated Watersheds Management on Climate-changing: Institutional side. In Watersheds Restoration. Solo, Central Java, Indonesia: Surakarta State University, pp. 43-62.

Evizal, R., Prijambada, I.D. \& Widada, D.A.N.J., 2012. Peranan Serasah Terhadap Sumbangan N dan P pada Agrosistem Kopi. Agrotrop, 2(2), pp.177-183.

FAO, 2014. Evidence-Based Assessment of The Sustainability and Replicability of Itegrated Food-Energy System, Rome, Italy: Food and Agriculture Organization of the United Natio.

Fitriani et al., 2018. Coffee Agroforestry Performance in Pulau Panggung Sub-district, Tanggamus , Lampung, Indonesia. Pelita Perkebunan, 34(2), pp.69-79.

Foran, T. et al., 2014. Taking complexity in food systems seriously: An interdisciplinary analysis. World Development, 61, pp.85-101.

Fu, Y. et al., 2009. Smallholder rubber plantation expansion and its impact on local livelihoods, land use and agrobiodiversity, a case study from Daka, Xishuangbanna, southwestern China. International Journal of Sustainable Development and World Ecology, 16(1), pp.22-29.

Haggar, J. et al., 2015. Tree diversity on sustainably certified and conventional coffee farms in Central America.

ICO, 2016. Annual Review 2015 - 2016,

Noponen, M.R. a et al., 2013. Intensification of coffee systems can increase the effectiveness of REDD mechanisms. Agricultural Systems, 119, pp.1-9. 
Somura, H. et al., 2018. Relationship between water quality variations and land use in the Batutegi Dam Watershed, Sekampung, Indonesia. Lakes \& Reservoirs: Research \& Management.

Xue, H. et al., 2013. Assessment of private economic benefits and positive environmental externalities of tea plantation in China. Environmental Monitoring and Assessment, 185(10), pp.8501-8516. 